\title{
Organik Koşullarda Yetiştirilen Bazı Kışlık Ekmeklik Buğday Genotiplerinde, Bazı Agronomik, Fizyolojik ve Teknolojik Özellikler Arasındaki İlişkilerin Saptanması
}

\author{
${ }^{*}$ Bilge BAHAR ${ }^{1}$ Necmiye BAHAR ${ }^{2}$ \\ ${ }^{1}$ Gümüşhane Üniversitesi, Müh. ve Doğa Bil. Fak., Gıda Müh. Bölümü, Gümüşhane \\ ${ }^{2}$ Gümüşhane Üniversitesi, Merkez Araştırma Laboratuvarı, Gümüşhane \\ *Sorumlu yazar e-posta (Corresponding author; e-mail): bilgebahar@gmail.com
}

\section{Öz}

Bu çalışma, 2012-2013 yetiştirme mevsiminde 19 kışlık ekmeklik buğday genotipi ile organik koşullarda, tesadüf blokları deneme desenine göre üç tekrarlamalı olarak yürütülmüş olup; çalışmada, agronomik, fizyolojik ve teknolojik özellikler arasındaki ilişkiler incelenmiştir. İncelenen özellikler arasındaki ilişkiler değerlendirildiğinde, tam çiçeklenme ve orta hamur olum dönemlerinde klorofil içeriklerinin protein oranı, yaş glüten oranı, enerji ve sedim değerleri arasındaki önemli olumlu ilişkileri, klorofil içeriklerine bağlı olarak kalite değerlerinin de arttığını göstermektedir. Yine tam çiçeklenme döneminde membran kararlılığının (MTS) protein oranı ve yaş gluten oranı arasındaki önemli olumlu ilişkiler, sıcağa dayanım kriteri olan MTS'nin kalite üzerindeki olumlu etkisini vurgulamaktadır. Çalışmada ayrıca, protein oranı, yaş glüten oranı, enerji, danede ve unda sedim değerlerinin, dane verimi ve biyolojik verimle olan önemli olumsuz ilişkileri; kalite ve verim arasındaki tezatlığı bir kez daha doğrulamıştır. Ayrıca, başaklanma süresi ile protein oranı, yaş glüten oranı, alveografik enerji değeri ve dane sedim değerleri arasında önemli olumlu ilişkiler bulunmuştur.

Anahtar Kelimeler: Ekmeklik buğday, verim, klorofil içeriği, MTS, kalite

\section{Determination of the Relationships among Some Agronomical, Physiological, and Technological Traits of Some Winter Bread Wheat Genotypes under Organic Conditions}

\begin{abstract}
This study was conducted with 19 winter bread wheat genotypes according to the completely randomized blocks design with three replication under organic conditions in the growth season of 2012-2013. In the study, relationships among agronomical, physiological, and technological traits were evaluated. Significant positive correlations of the chlorophyll contents which measured at full anthesis and soft dough ripeness stages with the protein content, wet gluten ratio, alveographic energy of whole grain and zeleny sedim of flour have indicated that quality values of the genotypes have increased depending on chlorophyll contents. Besides, the significant positive correlations of the membrane thermostability (MTS) measured at full anthesis with the protein content and wet gluten ratio have stressed the favorable effect of MTS on the quality traits, which is a heat and drought stress resistance criterion. In the study, the significant negative correlations of the grain yield and biomass with some technological traits such as protein content, wet gluten ratio, alveographic energy, and zeleny sedim on the whole grain have presented once more the contrast relationships between quality and yield. Also, heading time showed significant positive correlations with protein content, wet gluten ratio, energy, and zeleny sedim.
\end{abstract}

Keywords: Bread wheat, yield, chlorophyll content, MTS, quality

\section{Giriş}

D ünya'da ilk kültüre alınan bitkilerden olan buğday (Triticum spp.), stratejik bir bitki olup, insanların temel enerji ve protein kaynağı durumundadır. Dünya enerji gereksiniminin \%90'ı bitkisel kaynaklı olup, bunun da yarıya yakını (\%44'ü) ekmekten karşılanırken; ülkemizde günlük enerji ihtiyacının \%40 kadarı buğday ürünlerinden karşılanmaktadır (FAO 2008).

Buğday Dünya'da 220.6 milyon hektar ekim alanında 659.6 milyon ton üretilmekte olup 
ortalama tane verimi $299 \mathrm{~kg} / \mathrm{da}$ 'dır. Ülkemizde ise 8.1 milyon hektar ekim alanı, 20.1 milyon ton üretimi ve ortalama tane verimi $248 \mathrm{~kg} / \mathrm{da}$ ile en çok ekilen ve üretilen tarım ürünüdür (FAO 2013).

Bugüne kadar yürütülen ıslah çalışmalarında daha çok yüksek verim ile hastalık ve zararlılara dayanıklıık üzerinde durulduğu (Broadbent et al. 1987), ancak son yıllardaki eğilimin kullanılan girdileri daha etkin bir biçimde değerlendirebilen ve daha az girdi gerektiren çeşitlerin geliştirilmesi yönünde olduğu görülmektedir (Yıldırım ve ark. 2007).

Dünya genelinde buğday ıslah programları, bugüne kadar fizyolojik seleksiyon araçlarının yardımı olmaksızın önemli genetik ilerlemeler elde etseler de; son zamanlarda, bu ilerlemeyi arttırmada farklı disiplinlerin bir araya gelmesi gerektiği, bitki fizyologları ve ıslahçıların ortak görüşü olmuştur (Jackson et al. 1996). Bu nedenle, mevcut çeşit ıslahı tekniklerini tamamlayacak daha etkili ıslah yöntemlerine intiyaç duyulmaktadır.

Seleksiyon unsuru olarak kullanılan fizyolojik özellikler, verim yönünden genetik ilerlemeyi artırmada önemli etkiye sahip olup, buğday ıslahındaki etki mekanizmaları yoğun olarak araştırılmaktadır (Yıldırım ve ark. 2009). Son yıllarda yürütülen çalışmalar, stoma iletkenliği, fotosentez hızı, membran kararlıığı, bitki örtüsü serinliği ve klorofil içeriği gibi fizyolojik özelliklerin ıslahta seleksiyon kriteri olarak kullanılabileceğini ortaya koymaktadır (Reynolds ve ark. 2001; Koç ve ark. 2003; Yıldırım ve ark. 2009; Bahar ve ark. 2011).

$\mathrm{Bu}$ çalışmada, minimum girdili organik koşullarda; klorofil içeriği ve membran kararılığı gibi fizyolojik özelliklerin yanısıra bazı agronomik özellikler ve teknolojik özelliklerin birbirleriyle ilişkileri incelenmiştir.

\section{Materyal ve Yöntem}

Denemeler, 2012-2013 yetiştirme mevsiminde Gümüşhane Üniversitesi, Şiran Mustafa Beyaz MYO'nda, BAP projesi kapsamında kiralanan taban arazisi ile yüksekokulun Tohumluk ve Tahıl Teknolojisi Laboratuvarı'nda yürütülmüştür. Bu çalışmada, yedisi standart $(1,2,3,4,5,107$ ve 140 numaralı genotipler) olmak üzere toplam 19 ekmeklik buğday genotipi materyal olarak kullanılmıştır.

2012-2013 yetiştirme mevsimi toplam yağış miktarı $(436.8 \mathrm{~mm})$, uzun yıllar ortalamasından
(318.4 mm) yüksektir. 2012-2013 yetiştirme mevsiminde, en fazla yağış Aralık $(68.3 \mathrm{~mm})$ ve Mart (66.5 mm) aylarında gerçekleşirken; en az yağış Mayıs $(19.9 \mathrm{~mm})$ ve Temmuz $(9.6 \mathrm{~mm})$ aylarında alınmıştır. Ortalama sıcaklıklar bakımından, yetiştirme mevsiminde gözlenen değerlerle uzun yıllar ortalaması arasında önemli farklılıklar bulunmasa da, uzun yıllar ortalamasının üzerinde olduğu gözlenmiştir. Nispi nem değerleri bakımından; başaklanma ve dane dolum süreçlerinin gerçekleştiği generatif döneme denk gelen Haziran (\%50.1) ve Temmuz (\%46.8) aylarında, nispi nem değerlerinin fark edilir düzeyde uzun yıllar ortalamasından (sırayla \%63.0 ve \%60.6) düşük bulunduğu gözlenmiştir (Anonim, 2013).

Deneme alanı toprakları tekstür bakımından killi olup; tuzsuz (\%0.15), hafif alkali $(\mathrm{pH}=7.99)$, kireçli $\left(\% 10.66 \mathrm{CaCO}_{3}\right)$ sınıfına girmektedir. Ayrıca deneme topraklarının organik madde içeriği az (\%1.63) olup; fosforca $(1.95 \mathrm{~kg} / \mathrm{da})$ fakir, potasyumca $(14.91 \mathrm{~kg} / \mathrm{da})$ yeterlidir (Anonim, 2012).

Deneme, tesadüf blokları deneme desenine göre üç tekrarlamalı olarak kurulmuş; metrekareye 500 tohum düşecek şekilde, ekim işlemi, 19 Ekim 2012 tarihinde elle yapılmıştır. Her bir parsel $1.35 \mathrm{~m}$ (22.5'er cm aralıklı 6 sıra) x $5 \mathrm{~m}=6.75 \mathrm{~m}^{2}$ alanında olup; ekim zamanı dekara 2 ton organik büyükbaş hayvan gübresi $\left(\% 0.32 \mathrm{~N}, \% 0.16 \quad \mathrm{P}_{2} \mathrm{O}_{5}, \% 0.12 \quad \mathrm{~K}_{2} \mathrm{O}\right)$ ve kardeşlenme döneminde dekara $500 \mathrm{~kg}$ organik kanatlı gübresi (\%3 saf azot) verilmiştir. Olgunlaşmadan sonra parseller, orakla biçilip; Mono-Mak (MNHR-CD0025-BAH tipi) parsel harman makinesiyle harmanlanmıştır.

İncelenen özelliklerden, başaklanma süresi (gün), bitki boyu $(\mathrm{cm})$, başak uzunluğu $(\mathrm{cm})$, başakta dane sayısı (adet), başakta dane ağırlığı (g), biyolojik verim ( $\mathrm{kg} / \mathrm{da})$, hasat indeksi $(\%)$, dane verimi $(\mathrm{kg} / \mathrm{da})$, Bell ve Fischer (1994)'e göre incelenmiş; genotiplerin fenolojileri Zadoks Gelişme Skalasına (Zadoks ve ark. 1974) göre belirlenmiş; klorofil İçeriği, klorofil metre (SPAD 502 Plus) ile ZGS 69 (tam çiçeklenme) ve ZGS 85 (orta hamur olum) dönemlerinde, her parselde 10 adet bayrak yaprağın ortasında ölçülmüş ve ortalaması SPAD birimi olarak değerlendirilmiş; membran kararlıı̆̆ı Blum and Ebercon (1981)'ın bildirdiği yönteme göre saptanmıştır.

Teknolojik özelliklerden, bin dane ağırlığı (g) ve hektolitre ağırlığı $(\mathrm{kg} / \mathrm{hl})$, Yüksekokul Laboratuvarında; danede protein (\%), nem (\%), 
sertlik (birim), yaş gluten (\%), nişasta (\%), enerji $(\mathrm{J})$ ve sedim $(\mathrm{mL})$ gibi kalite parametreleri, Dicle Üniversitesi, Ziraat Fakültesi, Tarla Bitkileri Bölümü'nde NIT (Infratec 1241, FOSS) cihazı ile danede belirlenmiştir.

Verilerin değerlendirmesi, JMP (2007) paket programı kullanılmak suretiyle; tesadüf blokları deneme desenine göre yapılmıştır. Etkili farkları görmek için $F$ testi kullanılarak $P$ olasılık değerleri saptanmış; ortalama değerler arasındaki karşılaştırmalar, EGF testine göre yapılmıştır. İncelenen özellikler arasındaki ilişkiler yine JMP paket programıyla belirlenmiştir.

\section{Bulgular ve Tartışma}

Ekmeklik buğday genotiplerinin, başaklanma süresi, bitki boyu, başak uzunluğu, başakta dane sayısı ve başakta dane ağırlığı bakımından istatistiki olarak farklııı gösterirken; diğer agronomik özellikler (biyolojik verim, hasat indeksi ve dane verimi) bakımından farklı bulunmamıştır.

Ortalama değerler bakımından, başaklanma süresi 152.3 ile 162.0 gün; bitki boyu 50.9 ile $77.3 \mathrm{~cm}$; başak uzunluğu 7.04 ile $9.11 \mathrm{~cm}$; başakta dane sayısı 33.8 ile 48.0 adet; başakta dane ağırlığı 2.205 ile $2.948 \mathrm{~g}$ arasında değişim göstermiştir. İstatististiki olarak önemli farklılıklar göstermemekle birlikte; biyolojik verim 365.4 ile $643 \mathrm{~kg} / \mathrm{da}$; hasat indeksi \%36.5 ile \%45.4; dane verimi 151.5 ile $267.3 \mathrm{~kg}$ da-1 arasında değişim göstermiştir (Çizelge 1). Buna göre, biyolojik verim ve hasat indeksi bakımından yüksek değerler gösteren 47 ve 48 nolu genotipler, dane verimi bakımından da en üst sıralarda yer almıştır.

Klorofil içeriği bakımından tam çiçeklenme döneminde genotipler arasında farklılık

Çizelge 1. Ekmeklik Buğday Genotiplerinin Başaklanma Süresi (BS), Bitki Boyu (BB), Başak Uzunluğu (BU), Başakta Dane Sayısı (BDS), Başakta Dane Ağırlığı (BDA), Biyolojik Verim (BV), Hasat İndeksi (HI) ve Dane Verimi (DV)'ne İlişkin Ortalama Değerler.

Table 1. Days to Heading (BS), Plant Length (BB), Spike Length (BU), Kernel Number per Spike (BDS), Kernel Weight per Spike (BDA), Biomass (BV), Harvest Index (HI) and Grain Yield (DV) averages of bread wheat genotypes

\begin{tabular}{|c|c|c|c|c|c|c|c|c|c|c|c|c|c|}
\hline Genotip & $\begin{array}{c}\text { BS } \\
\text { (gün) }\end{array}$ & & $\begin{array}{l}\text { BB } \\
(\mathrm{cm})\end{array}$ & & $\begin{array}{l}\mathrm{BU} \\
(\mathrm{cm})\end{array}$ & & $\begin{array}{l}\text { BDS } \\
\text { (adet) }\end{array}$ & & $\begin{array}{c}\text { BDA } \\
\text { (g) }\end{array}$ & & $\begin{array}{l}\text { BV } \\
(\mathrm{kg} / \mathrm{da})\end{array}$ & $\begin{array}{l}\mathrm{HI} \\
(\%)\end{array}$ & $\begin{array}{c}D V \\
(\mathrm{~kg} / \mathrm{da})\end{array}$ \\
\hline 1 & 160.0 & $a b^{*}$ & 70.4 & $a b$ & 8.34 & $a-e$ & 43.3 & $a-d$ & 2.685 & $a b c$ & 425.2 & 41.3 & 175.5 \\
\hline 2 & 162.0 & $a$ & 77.3 & $\mathrm{a}$ & 9.11 & $a$ & 45.7 & $a b$ & 2.824 & $a b$ & 616.3 & 36.5 & 223.0 \\
\hline 3 & 161.3 & $a$ & 73.6 & $a b$ & 8.74 & $a b c$ & 43.0 & $a-d$ & 2.647 & $a b c$ & 643.0 & 37.9 & 246.5 \\
\hline 4 & 158.0 & $a b c$ & 66.5 & $b c$ & 8.32 & a-e & 48.0 & a & 2.642 & $a b c$ & 543.2 & 37.4 & 199.9 \\
\hline 5 & 157.3 & $a b c$ & 64.7 & $b-$ & 8.62 & $a-d$ & 42.2 & a-e & 2.612 & $a b c$ & 506.7 & 42.0 & 212.6 \\
\hline 107 & 152.7 & $c$ & 55.6 & $f-I$ & 7.84 & $b-f$ & 33.8 & f & 2.417 & $\mathrm{~cd}$ & 466.2 & 44.6 & 208.2 \\
\hline 140 & 154.7 & $\mathrm{bc}$ & 64.7 & b- & 8.77 & $a b$ & 36.9 & def & 2.390 & $\mathrm{~cd}$ & 456.3 & 40.0 & 181.8 \\
\hline 22 & 152.3 & $\mathrm{c}$ & 63.8 & $c-f$ & 8.72 & $a b c$ & 41.0 & a-f & 2.719 & $a b c$ & 476.1 & 37.8 & 173.8 \\
\hline 27 & 154.0 & $\mathrm{bc}$ & 54.7 & gh & 8.00 & $b-f$ & 38.7 & $b-f$ & 2.461 & bcd & 414.8 & 40.7 & 165.4 \\
\hline 28 & 154.3 & $\mathrm{bc}$ & 61.3 & d- & 7.75 & $c-f$ & 37.3 & $c-f$ & 2.406 & $\mathrm{~cd}$ & 473.1 & 43.9 & 207.0 \\
\hline 44 & 156.7 & $a b c$ & 59.2 & d- & 7.78 & $c-f$ & 37.6 & b-f & 2.375 & $\mathrm{~cd}$ & 570.4 & 38.6 & 224.8 \\
\hline 47 & 154.0 & $\mathrm{bc}$ & 60.3 & d- & 8.08 & $b-e$ & 42.9 & $a-d$ & 2.500 & bcd & 609.4 & 44.3 & 267.3 \\
\hline 48 & 154.7 & $\mathrm{bc}$ & 61.6 & c- & 8.22 & a-e & 41.9 & $a-f$ & 2.575 & $a-d$ & 598.5 & 43.2 & 254.6 \\
\hline 73 & 156.7 & $a b c$ & 56.9 & e- & 7.04 & $\mathrm{f}$ & 37.7 & $b-f$ & 2.375 & $\mathrm{~cd}$ & 414.8 & 43.1 & 174.9 \\
\hline 93 & 154.0 & $\mathrm{bc}$ & 56.3 & e- & 7.40 & ef & 45.5 & $a b c$ & 2.816 & $a b$ & 477.1 & 45.4 & 216.6 \\
\hline 114 & 152.7 & $c$ & 53.3 & gh & 8.25 & a-e & 43.2 & $a-d$ & 2.948 & a & 437.5 & 44.5 & 208.2 \\
\hline 133 & 153.7 & $c$ & 56.5 & e- & 7.69 & def & 39.2 & $b-f$ & 2.624 & $a b c$ & 452.4 & 40.7 & 191.3 \\
\hline 148 & 156.7 & $a b c$ & 50.9 & i & 7.05 & $f$ & 34.0 & ef & 2.205 & d & 376.3 & 40.5 & 151.5 \\
\hline 160 & 153.3 & $\mathrm{c}$ & 51.7 & hI & 7.62 & ef & 37.9 & b-f & 2.550 & bcd & 365.4 & 44.2 & 161.1 \\
\hline Ort. & 155.7 & & 61.0 & & 8.1 & & 40.5 & & 2.566 & & 490.7 & 41.4 & 200.9 \\
\hline$E F_{0}$ & 6.14 & & 9.02 & & 0.99 & & 8.30 & & 0.39 & & ÖD & ÖD & ÖD \\
\hline
\end{tabular}

${ }^{*}$ Aynı harf grubuna giren değerler, 0.05 önem düzeyine göre farklı değildir. EGF $0.05,0.05$ önem düzeyinde en küçük güvenilir fark. ÖD, önemli değil.

*Values followed by the same letters are not significantly different at 0.05. EGF 0.05 , Least significant difference at 0.05 level. ÖD, non significant. 
Çizelge 2. Ekmeklik Buğday Genotiplerinin Farklı Dönemlerde Ölçülen Klorofil İçerikleri ve Membran Kararlılığına İlişkin Ortalama Değerler.

Table 2. Average values of separate chlorophyll content and membrane thermostability measurements throughout growing season of bread wheat genotypes

\begin{tabular}{|c|c|c|c|c|c|c|c|}
\hline \multirow[t]{2}{*}{ Genotip } & \multicolumn{3}{|c|}{$\begin{array}{l}\text { Klorofil İçeriği } \\
\text { (SPAD Birimi) }\end{array}$} & \multicolumn{4}{|c|}{$\begin{array}{c}\text { Membran Kararlıığı } \\
(\%)\end{array}$} \\
\hline & \multicolumn{2}{|c|}{ ZGS 69} & \multirow{2}{*}{$\begin{array}{l}\text { ZGS } \\
85 \\
407\end{array}$} & \multirow{2}{*}{$\begin{array}{c}\text { ZGS } 69 \\
92.4\end{array}$} & \multicolumn{2}{|c|}{ ZGS 73} & \multirow{2}{*}{$\begin{array}{r}\text { ZGS } 85 \\
81.9\end{array}$} \\
\hline 1 & 48.7 & $a b^{*}$ & & & 94.1 & a & \\
\hline 2 & 46.4 & $a-e$ & 40.8 & 94.7 & 91.9 & $a b c$ & 82.9 \\
\hline 3 & 42.2 & $f$ & 39.7 & 91.7 & 89.6 & $a-d$ & 83.2 \\
\hline 4 & 47.4 & $a-d$ & 36.5 & 91.9 & 92.8 & $a b$ & 76.9 \\
\hline 5 & 45.7 & $b-f$ & 37.9 & 87.8 & 86.5 & $a-f$ & 83.2 \\
\hline 107 & 46.7 & $a-e$ & 32.7 & 80.0 & 85.0 & $b-f$ & 78.1 \\
\hline 140 & 45.2 & $b-f$ & 37.2 & 79.4 & 79.7 & ef & 78.7 \\
\hline 22 & 43.4 & def & 32.7 & 69.0 & 84.7 & $c-f$ & 83.2 \\
\hline 27 & 45.8 & $b-f$ & 37.2 & 85.2 & 79.1 & $f$ & 80.7 \\
\hline 28 & 50.1 & $a$ & 36.3 & 73.7 & 88.0 & $a-d$ & 84.2 \\
\hline 44 & 44.4 & $c-f$ & 30.0 & 90.2 & 83.3 & def & 74.4 \\
\hline 47 & 43.7 & def & 36.8 & 85.5 & 88.5 & $a-d$ & 84.6 \\
\hline 48 & 45.3 & $b-f$ & 27.7 & 82.2 & 89.6 & $a-d$ & 85.4 \\
\hline 73 & 42.8 & ef & 33.8 & 73.7 & 82.4 & def & 80.7 \\
\hline 93 & 43.6 & def & 36.0 & 79.9 & 88.5 & $a-d$ & 82.2 \\
\hline 114 & 48.3 & $a b c$ & 35.3 & 87.6 & 87.4 & $a-d$ & 79.4 \\
\hline 133 & 46.9 & $a-e$ & 35.7 & 76.0 & 85.5 & $b-f$ & 75.7 \\
\hline 148 & 42.1 & $f$ & 35.1 & 78.8 & 89.3 & $a-d$ & 78.9 \\
\hline 160 & 44.1 & $c-f$ & 35.4 & 83.0 & 86.7 & $a-f$ & 80.8 \\
\hline Ortalama & \multicolumn{2}{|c|}{45.4} & 35.7 & 83.3 & \multicolumn{2}{|c|}{87.0} & 80.8 \\
\hline $\mathrm{EGF}_{0.05}$ & \multicolumn{2}{|c|}{4.18} & ÖD & ÖD & \multicolumn{2}{|c|}{7.83} & ÖD \\
\hline
\end{tabular}

* Aynı harf grubuna giren değerler, 0.05 önem düzeyine göre farklı değildir. ZGS 69, tam çiçeklenme; ZGS 73, erken süt olum; ZGS 85, orta hamur olum dönemlerini göstermektedir $\mathrm{EGF}_{0.05}, 0.05$ önem düzeyinde en küçük güvenilir fark. ÖD, önemli değil.

*Values followed by the same letters are not significantly different at 0.05. ZGS 69, full anthesis, ZGS 73 early milk stage, ZGS 85, soft dough ripeness stage. $E G F_{0.05}$, Least significant difference at 0.05 level. ÖD, non significant

gözlenirken; orta hamur olum döneminde istatistiki olarak farklılık bulunmamıştır. Klorofil içerikleri bakımından ortalama değerler, tam çiçeklenme döneminde 42.1 ile 50.1 birim (SPAD); orta hamur döneminde 27.7 ile 40.8 birim arasında değişim göstermiştir. Ekmeklik buğday genotipleri, membran kararlılı̆ı (MTS) bakımından değerlendirildiğinde; istatistiki farklılıklar sadece erken süt olum döneminde ortaya çıkmış; diğer gelişme dönemlerinde (tam çiçeklenme ve orta hamur olum) genotipler farklılık göstermemiştir. Buna göre, MTS; tam çiçeklenme döneminde \%69.0 ile 94.7; erken süt olum döneminde $\% 79.1$ ile 94.1 ; orta hamur olum döneminde \%74.4 ile 85.4 arasında değişim göstermiştir (Çizelge 2).

Teknolojik özelliklerden hektolitre ağırlığı, bin dane ağırlığı, dane nemi, sertlik ve nişasta oranı istatistiki olarak önemli farklılıklar göstermiştir. Buna göre hektolitre ağırlığı 82.80 ile 85.67 $\mathrm{kg} / \mathrm{hl}$, bin dane ağırlığı 31.38 ile $40.32 \mathrm{~g}$, dane nemi \%10.74 ile 11.32, dane sertliği 114.8 ile 115.4 birim, nişasta oranı (kuru madde bazında) \%61.7 ile 63.8 arasında değişmiştir. Diğer kalite özelliklerinden protein, yaş gluten, enerji ve sedim bakımından ekmeklik buğday genotipleri arasında farklılık bulunmamakla birlikte; genotiplerin protein oranı kuru madde bazında \%13.0 ile 14.7, yaş gluten oranı \%29.8 ile 34.6, enerji 275 ile $322 \mathrm{~J}$ ve sedim 50.3 ile $58.6 \mathrm{~mL}$ arasında değişim göstermiştir (Çizelge 3).

\section{İncelenen Özellikler Arasındaki İlişkiler}

Biyolojik verim: dane verimi $\left(r=0.892^{* *}\right)$, nişasta oranı $\left(r=0.489^{* *}\right)$, bitki boyu $\left(r=0.597^{* *}\right)$, başak uzunluğu $\left(r=0.296^{*}\right)$, başakta dane sayısı $\left(r=0.452^{* *}\right)$, başakta dane ağırlığı $\left(r=0.345^{* *}\right)$, ile olumlu ilişkili, hasat indeksi $\left(r=-0.334^{*}\right)$, orta hamur olum döneminde klorofil içeriği ( $r=-$ $\left.0.304^{*}\right)$, protein oranı $\left(r=-0.542^{* *}\right)$, dane nemi $(r$ $\left.=-0.489^{* *}\right)$, yaş glüten $\left(r=-0.516^{* *}\right)$, enerji $(r=-$ $\left.0.446^{* *}\right)$ ve sedim $\left(r=-0.492^{* *}\right)$ ile olumsuz ilişkili; Hasat indeksi: dane nemi $\left(r=0.460^{* *}\right)$ ile olumlu ilişkili, başaklanma süresi $\left(r=-0.335^{*}\right)$, bitki boyu ( $\left.r=-0.526^{* *}\right)$ ve nişasta oranı ( $r=$ $0.252^{*}$ ) ile olumsuz ilişkili; Dane verimi: bitki boyu $\left(r=0.377^{* *}\right)$, başakta dane sayısı $\left(r=0.452^{* *}\right)$, başakta dane ağırlığı $\left(r=0.321^{*}\right)$, erken süt olum döneminde membran kararlılığı, 
MTS $\left(r=0.317^{*}\right)$ ve nişasta oranı $\left(r=0.402^{* *}\right)$ ile olumlu ilişkili, orta hamur olum döneminde klorofil içeriği $\left(r=-0.352^{* *}\right)$, protein içeriği $(r=-$ $\left.0.545^{* *}\right)$, dane nemi $\left(r=-0.307^{\star}\right)$, yaş glüten $(r=-$ $\left.0.535^{\star *}\right)$ ve sedim $\left(r=-0.561^{* *}\right)$ ile olumsuz ilişkili; Başaklanma süresi: bitki boyu $\left(r=0.424^{* *}\right)$, orta hamur olum döneminde klorofil içeriği $\left(r=0.457^{* *}\right)$, protein içeriği $\left(r=0.380^{* *}\right)$, yaş glüten $\left(r=0.469^{* *}\right)$, enerji $\left(r=0.322^{*}\right)$ ve danede sedim $\left(r=0.462^{* *}\right)$ ile olumlu ilişkili; Bitki boyu: başak uzunluğu $\left(r=0.606^{* *}\right)$, başakta dane sayısı $\left(r=0.392^{* *}\right)$, başakta dane ağırlığı $\left(r=0.374^{* *}\right)$ ve nişasta oranı $\left(r=0.336^{*}\right)$ ile olumlu, dane nemi $\left(r=-0.406^{* *}\right)$ ile olumsuz ilişkili; Başak uzunluğu: başakta dane sayısı $\left(r=0.399^{* *}\right)$ ve başakta dane ağırlığı $\left(r=0.541^{* *}\right)$ ile olumlu ilişkili; Başakta dane sayısı: başakta dane ağırlığı $\left(r=0.775^{* *}\right)$ ve erken süt olum döneminde MTS $\left(r=0.362^{* *}\right)$ ile olumlu ilişkili; Başakta dane ağırlığı: tam çiçeklenme döneminde klorofil içeriği $\left(r=0.271^{*}\right)$ ile olumlu ilişkili; Tam çiçeklenme döneminde klorofil içeriği: protein içeriği $\left(r=0.278^{*}\right)$, dane nemi $\left(r=0.282^{*}\right)$, yaş glüten $\left(r=0.262^{*}\right)$ ve enerji $\left(r=0.322^{*}\right)$ ile olumlu ilişkili; Orta hamur olum döneminde klorofil içeriği: protein içeriği $(r=$ $\left.0.505^{\star \star}\right)$, yaş gluten $\left(r=0.530^{\star \star}\right)$, enerji $\left(r=0.361^{*}\right)$ ve sedim $\left(r=0.519^{* *}\right)$ ile olumlu, nişasta oranı $\left(r=-0.372^{* *}\right)$ ile olumsuz ilişkili; Tam çiçeklenme döneminde membran kararlıı̆̆ (MTS): erken süt olum döneminde belirlenen MTS $\left(r=0.351^{* *}\right)$, protein içeriği $\left(r=0.279^{*}\right)$ ve yas glüten $\left(r=0.294^{*}\right)$ ile olumlu, bin dane ağırlığı ile olumsuz ( $\left.r=-0.280^{*}\right)$ ilişkili; Erken süt olum döneminde MTS: dane nemi $\left(r=0.267^{*}\right)$ ile olumlu ilişkili; Orta hamur olum döneminde MTS: hektolitre ağırlığı $\left(r=0.269^{*}\right)$ ile olumlu ilişkili; Hektolitre ağırlığı ile bin dane ağırlığı $\left(r=-0.310^{*}\right)$ olumsuz ilişkili; Protein içeriği: dane nem içeriği $\left(r=0.430^{* *}\right)$, yaş glüten $\left(r=0.972^{* *}\right)$, enerji $\left(r=0.833^{* *}\right)$ ve sedim $\left(r=0.856^{* *}\right)$ ile olumlu, nişasta oranı ile olumsuz $\left(r=-0.705^{* *}\right)$ ilişkili; Dane nem içeriği: yaş glüten $\left(r=0.449^{* *}\right)$ ve sedim değeri $\left(r=0.267^{*}\right)$ ile olumlu, nişasta oranı ile olumsuz $\left(r=-0.574^{* *}\right)$ ilişkili; Dane sertliği: nişasta $\left(r=-0.259^{*}\right)$ ve sedim değeri $\left(r=-0.258^{*}\right)$ ile olumsuz ilişkili; Yaş glüten: sedim $\left(r=0.845^{* \star}\right)$ ve enerji $\left(r=0.791^{* *}\right)$ ile olumlu, nişasta içeriği ile olumsuz ( $r=-$ $\left.0.598^{* *}\right)$ ilişkili; Nişasta içeriği: enerji $(r=-$ $\left.0.530^{* *}\right)$ ve sedim $\left(r=-0.492^{* *}\right)$ ile olumsuz ilişkili; Enerji: sedim değeri ile olumlu $\left(r=0.831^{* *}\right)$ ilişkili bulunmuştur.

Çizelge 3. Ekmeklik Buğday Genotiplerinin Teknolojik Ozelliklerine Ilişkin Ortalama Değerler.

Table 3. Average values of technological properties of bread wheat genotypes

\begin{tabular}{|c|c|c|c|c|c|c|c|c|c|c|}
\hline Genotip & \multicolumn{2}{|c|}{$\begin{array}{l}\text { H.Ağırlığı } \\
(\mathrm{kg} / \mathrm{hl})\end{array}$} & $\begin{array}{l}\text { Bin Dane } \\
\text { Ağırlığı } \\
(\mathrm{g})\end{array}$ & $\begin{array}{c}\text { Protein } \\
(\%)\end{array}$ & $\begin{array}{c}\text { Nem } \\
(\%)\end{array}$ & $\begin{array}{l}\text { Sertlik } \\
\text { (Birim) }\end{array}$ & $\begin{array}{c}\text { Yaş } \\
\text { Gluten } \\
(\%)\end{array}$ & $\begin{array}{c}\text { Nişasta } \\
(\%)\end{array}$ & $\begin{array}{l}\text { Enerji } \\
(\mathrm{J})\end{array}$ & $\begin{array}{c}\text { Sedim } \\
(\mathrm{mL})\end{array}$ \\
\hline 1 & 83.53 & $d e^{*}$ & 36.64 a-d & 14.7 & $11.32 \mathrm{a}$ & $114.8 \mathrm{a}$ & 34.6 & $61.8 \mathrm{f}$ & 322 & 58.6 \\
\hline 2 & 84.60 & $b$ & $35.74 \mathrm{bcd}$ & 14.3 & $10.91 \mathrm{~b}-\mathrm{e}$ & $113.8 \mathrm{ab}$ & 33.9 & 62.3 def & 309 & 58.0 \\
\hline 3 & 82.87 & $f$ & $35.71 \mathrm{bcd}$ & 13.4 & $10.74 \mathrm{e}$ & $103.7 \mathrm{e}$ & 31.8 & $63.6 \mathrm{ab}$ & 297 & 55.7 \\
\hline 4 & 83.67 & $\mathrm{~cd}$ & 34.10 cde & 13.1 & 10.85 cde & $115.4 \mathrm{a}$ & 30.1 & 63.4 a-d & 291 & 52.9 \\
\hline 5 & 83.07 & ef & 35.24 b-e & 14.1 & $10.98 \mathrm{~b}-\mathrm{e}$ & $111.2 \mathrm{a}-\mathrm{d}$ & 32.6 & $62.4 c-f$ & 300 & 56.3 \\
\hline 107 & 82.80 & $f$ & $38.17 \mathrm{ab}$ & 13.4 & $11.14 a b$ & $113.7 \mathrm{ab}$ & 31.0 & 61.9 ef & 313 & 53.9 \\
\hline 140 & 83.60 & cde & $40.32 \mathrm{a}$ & 13.0 & 10.89 b-e & $112.1 \mathrm{a}-\mathrm{d}$ & 29.8 & 63.0 a-e & 290 & 56.7 \\
\hline 22 & 84.13 & $\mathrm{bc}$ & $36.71 \mathrm{a}-\mathrm{d}$ & 13.7 & $10.88 \mathrm{~b}-\mathrm{e}$ & $108.0 \mathrm{de}$ & 31.2 & 63.1 a-e & 313 & 56.0 \\
\hline 27 & 84.13 & $\mathrm{bc}$ & 34.79 b-e & 13.9 & $10.95 b-e$ & $108.8 \mathrm{~cd}$ & 32.5 & $63.2 \mathrm{a}-\mathrm{d}$ & 303 & 55.2 \\
\hline 28 & 85.40 & $a$ & $33.80 \mathrm{de}$ & 14.5 & $10.80 \mathrm{de}$ & $108.2 \mathrm{de}$ & 34.1 & $63.2 \mathrm{a}-\mathrm{d}$ & 313 & 58.5 \\
\hline 44 & 83.93 & $\mathrm{~cd}$ & 34.48 b-e & 13.5 & 10.97 b-e & 113.2 & 31.1 & $62.5 b-f$ & 283 & 53.5 \\
\hline 47 & 85.67 & $a$ & $31.38 \mathrm{e}$ & 13.4 & $11.00 \mathrm{~b}-\mathrm{e}$ & 109.6 & 31.3 & 63.1 a-e & 283 & 53.0 \\
\hline 48 & 84.60 & $b$ & $36.58 \mathrm{a}-\mathrm{d}$ & 13.0 & $10.89 \mathrm{~b}-\mathrm{e}$ & $112.0 \mathrm{a}-\mathrm{d}$ & 30.5 & $63.8 \mathrm{a}$ & 275 & 50.3 \\
\hline 73 & 82.93 & $f$ & $37.70 \mathrm{abc}$ & 13.3 & 10.82 cde & 110.2 & 30.9 & 63.6 & 300 & 56.1 \\
\hline 93 & 84.07 & bcd & $35.48 \mathrm{bcd}$ & 13.9 & $10.97 \mathrm{~b}-\mathrm{e}$ & $108.2 \mathrm{de}$ & 31.9 & $62.6 \mathrm{~b}-\mathrm{f}$ & 297 & 57.1 \\
\hline 114 & 82.80 & $\mathrm{f}$ & $33.80 \mathrm{de}$ & 14.3 & $10.92 \mathrm{~b}-\mathrm{e}$ & 113.1 & 32.9 & $61.7 \mathrm{f}$ & 304 & 57.5 \\
\hline 133 & 82.87 & $f$ & 34.52 b-e & 14.1 & $11.04 \mathrm{a}-\mathrm{d}$ & 112.7 & 33.0 & 62.6 b-f & 301 & 56.6 \\
\hline 148 & 83.53 & de & $36.41 \mathrm{bcd}$ & 14.4 & $11.10 \mathrm{abc}$ & $113.9 \mathrm{ab}$ & 33.7 & $61.8 \mathrm{f}$ & 306 & 57.7 \\
\hline 160 & 84.60 & $\mathrm{~b}$ & 35.09 b-e & 13.8 & $11.15 a b$ & $112.0 \mathrm{a}-\mathrm{d}$ & 32.4 & 62.9 a-f & 295 & 56.5 \\
\hline & 83.83 & & 35.61 & 13.8 & 10.96 & 111.3 & 32.1 & 62.8 & 300 & 55.8 \\
\hline$E F_{0.05}$ & 0.58 & & 3.89 & ÖD & 0.29 & 4.49 & ÖD & 1.22 & ÖD & ÖD \\
\hline
\end{tabular}

* Aynı harf grubuna giren değerler, 0.05 önem düzeyine göre farklı değildir. $\mathrm{EGF}_{0.05}, 0.05$ önem düzeyinde en küçük güvenilir fark. ÖD, önemli değil

${ }^{*}$ Values followed by the same letters are not significantly different at 0.05. EGF 0.05 , Least significant difference at 0.05 level. ÖD, non significant. 
Dane verimi ile biyolojik verim arasındaki önemli olumlu ilişki, Reynolds et al. (2000) tarafından da vurgulanmıştır. Ayrıca, biyolojik verimle doğrudan olumlu ilişkileri bulunan bitki boyu ve başak uzunluğu gibi tarımsal özelliklerin hasat indeksi ile olumsuz ilişkiler gösterdiği saptanmıştır. Nitekim, Fischer et al. (1981) bitki boyunun, dane verimi, dane sayısı ve hasat indeksi ile olumsuz ilişkiler gösterdiğini belirtmişlerdir. Ancak, bu çalışmada bitki boyu, dane verimi ve başakta dane sayısı ile olumlu ilişkiler göstermiştir. Fizyolojik özelliklerden klorofil içeriği, Yıldırım ve ark. (2011)'nın başaklanma ve erken süt olum döneminde buldukları sonuçlara benzer olarak, tam çiçeklenme döneminde dane verimi ile olumlu ilişki bulunurken; orta hamur olum döneminde ilişki bulunmamıştır. Ortalama değerler incelendiğinde, 47 ve 48 nolu hatların kuru koşullarda yüksek verim göstermelerinin yanısıra, erkenci, kısa boylu, kalın saplı, kapalı kavuzlu, parsel görünümü iyi, başakları orta uzunlukta, başakta dane sayısı ve başakta dane ağırlığı (başak verimi) yüksek, kışın sert soğuklarına ve hastalıklara dayanıklı genotipler olarak da dikkati çekmektedir. Nitekim, Genç ve ark. (2003) bu özelliklere sahip buğday çeşitlerinin elde edilmesinin Islah çalışmalarında esas teşkil ettiğini belirtmişlerdir. Araştırıcıların da değindiği üzere, erkencilik yüksek verim için önemli bir özelliktir. Ancak, yapılan bu çalışmada, başaklanma süresi ile dane verimi arasında önemli ilişki bulunmamakla birlikte; hasat indeksi ile önemli olumsuz ilişki göstermesi, erkenciliğin önemini bir kez daha vurgulamıştır. Çünkü, erkenci genotiplerin dane doldurma için daha fazla süre kazanmaları, onların hasat indeksini de artırmış olacaktır. Ayrıca, başaklanma süresi ile orta hamur olum döneminde (ZGS 85) klorofil içeriği arasında olumlu ilişkiler bulunması, erkenci çeşitlerin bu dönemde klorofil kaybetmeleri nedeniyle daha az klorofil içerdiğini; geççilerin ise bu dönemde hala yeşil kalmaları nedeniyle klorofil oranlarının yüksek olduğunu göstermektedir. Ayrıca erkenci genotipler, tam çiçeklenme döneminde (ZGS 69) düşük membran kararlılığı (MTS) göstermiştir. Bununla birlikte, erken süt olum döneminde (ZGS 73) MTS ile dane verimi arasındaki önemli olumlu ilişki, MTS'nin önemini vurgulamaktadır. Tam çiçeklenme döneminde MTS'si yüksek olan genotiplerin küçük bin dane ağırlığına sahip olduğu; böyle genotiplerin hektolitre ağırlıklarının da yüksek olduğu ortaya konmuştur. Tam çiçeklenme döneminde
MTS'nin, protein içeriği ve yaş glüten içeriği ile olumlu ilişkili olduğu ortaya konmuş; başka bir deyişle, bu dönemde yüksek membran kararlılığı gösteren genotiplerde protein birikimi ve glüten oluşumunun daha yüksek olduğu söylenebilir. Bu çalışmada, protein içeriği, yaş glüten, enerji, danede sedim değerlerinin tane verimi ve biyolojik verimle önemli olumsuz ilişkiler göstermesi; verimle kalite arasındaki ters ilişkiyi bir kez daha ortaya koymaktadır. Teknolojik özelliklerden, nişasta oranı ile protein içeriği arasındaki önemli olumsuz ilişki; endospermde protein yerine nişasta birikiminin artışının protein oranını azaltacağını belirten İskender ve ark. (1994)'nın bulgularıyla paralellik göstermektedir.

\section{Sonuç}

Tam çiçeklenme döneminde membran kararlıı̆ının (MTS) protein oranı ve yaş gluten oranı arasındaki önemli olumlu ilişkiler, sıcağa dayanım kriteri olan MTS'nin kalite üzerindeki olumlu etkisini vurgulamaktadır. Ayrıca, dane verimi ve biyolojik verim ile protein oranı, yaş glüten oranı, enerji değeri ve sedim değerleri arasında olumsuz ilişki tespit edilmiştir.

\section{Teşekkür}

Bu araştırma, Gümüşhane Üniversitesi BAP Koordinatörlüğünce desteklenmiştir. Proje No: 13.B0423.02.1

\section{Kaynaklar}

Anonim, 2012. Kahramanmaraş Sütçü İmam Üni., Toprak Bölümü Lab. Analiz Sonuçları. Kahramanmaraş

Anonim, 2013. Gümüşhane İli Meteoroloji Müdürlüğü Aylık Hava Raporları. Gümüşhane

Bahar B., Yıldırım M. ve Yucel C., 2011. Heat and drought resistance criteria in spring bread wheat (Triticum aestivum L.): Morphophysiological parameters for heat tolerance. Scientific Research and Essays, 6(10): 22122220

Bell M.A. and Fischer R.A., 1994. Guide to Plant and Crop Sampling: Measurements and Observations for Agronomic and Physiological Research in Small Grain Cereals. Wheat Special Report, 32, CIMMYT, Mexico

Blum A. and Ebercon A., 1981. Cell Membrane Stability as a Measure of Drought and Heat Tolerance in Wheat. Crop Science, 21: 43-47-

Broadbent F.E., De Datta S.K and Laureles EV, 1987. Measurement of Nitrogen Utilization Efficiency in Rice Genotypes. Agronomy Journal, 79(5): 786-791 
Bahar ve Bahar "Organik Koşullarda Yetiştirilen Bazı Kışlık Ekmeklik Buğday Genotiplerinde, Bazı Agronomik, Fizyolojik ve Teknolojik Özellikler Arasındaki Illişkilerin Saptanması"

FAO, 2008. Food and Agriculture Organization of the United Nations, Rome, www.fao.org

FAO, 2013. Food and Agriculture Organization of the United Nations, Rome, www.fao.org.Fischer R.A., Bidinger F., Syme J.R. and Wall P.C, 1981. Leaf photosynthesis, leaf permeability, crop growth, and yield of short spring wheat genotypes under irrigation. Crop Sci., 21: 367-373

Genç I., Yağbasanlar T., Özkan H., Yıldırım M., Yücel C., Özer S., Bahar B., Altıntaş S. ve Topal M., 2003. Çukurova Koşullarına Uygun Buğday Islah Çalışmaları. Türkiye 5. Tarla Bitkileri Kongresi, Ekim 2003, Diyarbakır, Tarla Bitkileri Islahı Bildiriler Kitabı: 41-46

Iskender F.A., Emad M., Maarof A.L., Muhammed O., Aubaidi A.L., Kazal K., Janabi A.L., Abdulbased A., Laith A.L., Rawi A.A. and Ali H.A., 1994. New Wheat Cultivars Introduced by Fast Neutrons in Iraq. Rachis.13: 1-2

Jackson P., Robertson M., Cooper M. and Hammer G., 1996. The role of physiological understanding in plant breeding from a breeding perspective. Field Crops Res., 49: 11-37

JMP, 2007. SAS Institute Inc., Cary, North Carolina 27513, USA

Koç M., Barutçular C. ve Genç ì., 2003. Photosynthesis and productivity of old and modern durum wheats in a mediterraean enivironment. Crop Science, 43(6): 20892097
Reynolds M.P., Delgado B.M.I., Gutierre-Rodriguez M. and Larque-Saavedra A., 2000. Phosynthesis of wheat in a warm, ırrigated environment I: Genetic diversity and crop productivity. Field Crops Research, 66: 37-50

Reynolds M.P., Nagarajan S., Razzaque M..A. and Ageeb O.A.A., 2001. Heat Tolerance. Application of Physiology in Wheat Breeding. (Eds: M.P. Reynolds, I. Ortiz-Monasterio, A. McNab). Mexico, DF, CIMMYT

Yıldırım M., Akıncı C., Koç M. ve Barutçular C., 2009. Bitki örtüsü serinliği ve klorofil miktarının makarnalık buğday ıslahında kullanım olanakları. Anadolu Tarım Bilim Dergisi, 24(3):158-166

Yıldırım M., Bahar B., Genc I., Korkmaz K. ve Karnez E., 2007. Diallel analysis of wheat parents and their $F_{2}$ progenies under medium and low level of available $\mathrm{N}$ in soil. Plant Nutrition, 30 : 937-945

Yıldırım M., Kılıç H., Kendal E. ve Karahan T., 2011. Applicability of chlorophyll meter readings as yield predictor in durum wheat. Journal of Plant Nutrition, 34: 151-164

Zadoks J.C., Chang T.T. and Konzak C.F., 1974. A decimal code for the growth stages of cereals. Weeds Research, 14: 412-415 